\begin{tabular}{l|l} 
Variants & $\begin{array}{l}\text { Variants } \\
\text { The Journal of the European Society for Textual } \\
\text { Scholarship }\end{array}$
\end{tabular}

12-13 | 2016

Varia

\title{
Fernando Pessoa, Apreciações Literárias
}

\section{Carlota Pimenta}

URL: http://journals.openedition.org/variants/389

DOI: $10.4000 /$ variants.389

ISSN: 1879-6095

\section{Publisher}

European Society for Textual Scholarship

\section{Printed version}

Date of publication: 31 December 2016

Number of pages: 253-255

ISSN: 1573-3084

\section{Electronic reference}

Carlota Pimenta, « Fernando Pessoa, Apreciações Literárias », Variants [Online], 12-13 | 2016, Online since 01 May 2017, connection on 25 September 2020. URL : http://journals.openedition.org/variants/ 389 ; DOI : https://doi.org/10.4000/variants.389

This text was automatically generated on 25 September 2020 .

The authors 


\title{
Fernando Pessoa, Apreciações Literárias
}

\author{
Carlota Pimenta
}

\section{REFERENCES}

Fernando Pessoa, Apreciações Literárias. Ed. Pauly Ellen Bothe, Lisbon, Imprensa Nacional-Casa da Moeda, 2013.

1 The critical edition of the works of Fernando Pessoa (1888-1935) is an editorial project which has carried out its mission to bring out scholarly editions of the Portuguese modernist author since 1988. The outputs of the project have appeared two series, "Edição da Obra Completa de Fernando Pessoa" (The Edition of the Complete Work of Fernando Pessoa) and "Estudos sobre o Espólio Pessoano" (Studies on Pessoa's Archive). The former, in its (so-called) "Major Series", contains the critical editions of Pessoa's writings: here the text is accompanied by a philologically-oriented introduction, notes and two critical apparatuses with (rich) genetic information and with reading variants. In addition to this series (mainly intended for a scholarly audience), of which nineteen volumes have already been put into print, the project also contemplates the publication of a "Minor Series", which is directed to the common reader and only includes an introductory essay and the unannotated critical text.

2 The "Estudos" series, which was created to publish essays on Pessoa's work, has to date issued four volumes, of which Apreciações Literárias de Fernando Pessoa (Fernando Pessoa's Literary Appreciations) edited by Pauly Ellen Bothe is a recent volume. The texts that Bothe has brought together were never published by Pessoa as a collection; the title of the volume, Apreciações Literárias, refers to the section of Pessoa archive at the National Library of Portugal (E3) where most of them can be found.

3 The volume opens with an introduction which gives a brief account of the editorial criteria. Although Bothe follows the guidelines used for the Major series, a reader not familiar with the other editions might perhaps welcome a more detailed description of the editorial goals in this volume and of the methods used, which combine the 
identification of the genetic stages in the writing process with the selection of the last stage to serve as the basis for the reading text.

After the introduction, the reader finds the critically edited text of 372 documentsmost of which were hitherto unpublished - containing Pessoa's reflections on the writings of 98 authors from various periods and different nationalities (including, among others, Charles Baudelaire, William Blake, Charles Dickens, Gustave Flaubert, Johann Wolfgang von Goethe, Victor Hugo, James Joyce, John Keats, John Milton, Molière, Edgar Allan Poe, Jean Jacques Rousseau, William Shakespeare, Leo Tolstoy, Oscar Wilde and Émile Zola). Organized, as it were, as a dictionary of literary opinion, the texts are alphabetically ordered by author name and, to facilitate consultation, the volume closes with a topographical and an onomastic index.

The edition of these critical reviews is the result of painstaking work of collecting, organizing and laboriously transcribing Pessoa's texts on these writers. All the works Pessoa referred to and commented on, including those of which he owned a copy in his personal library, are identified in the footnotes of the critical text. Therefore, the reader has the possibility of checking the bibliographical background of Pessoa's reflections.

6 Because the genetic and critical apparatuses are so bulky, owing to the amount of corrections and revisions and difficulties with deciphering the handwriting, they have been placed separately in the second part of the volume. The genetic apparatus describes historically how the text reached its last known state; the apparatus of reading variants highlights the differences between the reading text of the edition and the ones conveyed by previous editions. Under the title or incipit of each text, Bothe offers a description of the materials used by Pessoa, which is followed by the genetic apparatus, the apparatus of reading variants and an appendix with additional archival information regarding the text.

7 While the apparatus is a rich resource with detailed information about how the genesis and transmission of Pessoa's texts, it might have been useful to include references to Páginas de Doutrina Estética (edited by Jorge de Sena [Lisbon: Inquérito, 1946]) and to Apreciações Literárias: Bosquejos e Esquemas Críticos (Porto: Arcádia, 1951) which contain other texts in which Pessoa gives his literary opinions.

Pauly Ellen Bothe's efforts to decipher Pessoa's texts are quite impressive and as a rule overcome the immense challenge associated with Pessoa's often impenetrable handwriting: her transcriptions offers quite a few improvements from previous editions. Her edition thus represents a significant step forward in the scholarship dedicated to this part of Pessoa's work. A few lapses -- such as "sono" (sleep) for "sonho" (dream) (38) or "admiravel" (admirable / remarkable) for "adoravel" (adorable) (492) do not mar the impression that the edition of Apreciações Literárias is a relevant work of textual scholarship and constitutes an immensely useful instrument for the reader who wishes to study these texts from a literary, philological or linguistic perspective. 


\section{AUTHORS}

\section{CARLOTA PIMENTA}

Carlota Pimenta is a researcher at the Centre for Linguistics of the University of Lisbon (CLUL). She is currently working on her PhD project in the field of Textual Criticism. Carlota is member of the team which is preparing the critical and genetic editions of the great nineteenth-century novelist Camilo Castelo Branco as well as of the team who is working on the critical edition of Crónica de D. João I, by the great chronicler Fernão Lopes. 